\title{
Physiological comparisons of Pacific cupped oysters at different levels of ploidy and selection to OsHV-1 tolerance
}

\author{
Haure Joël ${ }^{1,}{ }^{*}$, François Cyrille ${ }^{1}$, , ${ }^{*}$ Dégremont Lionel ${ }^{1}$, Ledu Christophe ${ }^{1}$, Maurouard Elise ${ }^{1}$, \\ Girardin Frédéric ${ }^{2}$, Benabdelmouna Abdellah ${ }^{1}$
}

\author{
${ }^{1}$ IFREMER, RBE-SG2M-LGPMM, Station La Tremblade, Ave Mus Loup, F-17390 La Tremblade, \\ France \\ 2 IFREMER, RBE-SG2M-PMMLT, Station La Tremblade, Ave Mus Loup, F-17390 La Tremblade, \\ France \\ * Corresponding authors : Joël Haure, email address : joel.haure@ifremer.fr ; Cyrille François, email \\ address : cyrille.francois@ifremer.fr
}

lionel.degremont@ifremer.fr ; christophe.ledu@ifremer.fr ; elise.maurouard@ifremer.fr ; frederic.girardin@ifremer.fr ; abdellah.benabdelmouna@ifremer.fr

\begin{abstract}
:
The production and supply of triploid oysters Crassostrea gigas has become an increasingly frequent activity in aquaculture companies to satisfy the growing demand of growers. These triploid oysters are usually obtained by crossing male tetraploid oysters with female diploid oysters. Furthermore, studies have shown that it is possible to select oysters for better resistance to infection by OsHV-1 and they are currently produced by commercial hatcheries in France.
\end{abstract}

The effects of ploidy and selection on the physiological functioning of the Pacific cupped oyster are still relatively unknown, especially in tetraploid animals selected for better resistance to infection by OsHV-1. In the framework of sustainable domestication, and by taking into account the natural habitat, it has become necessary to shed more light on the subject.

Faced by this lack of knowledge, a physiological study of respiration and clearance rate was performed on 6 stocks of $\mathrm{C}$. gigas oysters whose levels of ploidy (2n, $3 \mathrm{n}$ and $4 \mathrm{n}$ ) and sensitivity to OsHV-1 resistance (selected and non-selected) were different. The experiments were performed in controlled and reproducible habitats where OsHV-1 is absent.

The physiological results showed: i) an absence of interaction between ploidy levels and selection; ii) families showed no significant difference as a function of the level of selection to OsHV-1 tolerance; and iii) significant differences in clearance rate and daily weight growth as a function of the oysters' ploidy level.

In particular, the results revealed that the clearance rate of tetraploids was lower than that of diploid and triploid oysters with a growth rate equal to that of triploids and higher than diploids.

Additional studies are envisaged in the discussion to better understand these results. 


\section{Highlights}

- The production and supply of triploid oysters Crassostrea gigas has become an increasingly frequent activity in aquaculture companies to satisfy the growing demand of breeders. The effects of ploidy and selection for better resistance to pathogens, on the physiological functioning of the Pacific cupped oyster are still relatively unknown, especially in tetraploid oysters. - The interest of this study is to verify the effects of selection and ploidy on the physiological performances of cultivated oysters.

Keywords : Oyster, Physiology, Ploidy, Selection 


\section{Introduction}

The use of polyploid animals is increasingly frequent in aquaculture farms (Piferrer et al., 2009). The economic profitability is enhanced by the rapid growth, disease resistance and organoleptic quality of polyploid animals. (Zhou and Gui, 2017; Nell, 2002).

In the oyster farming sector, the production of triploid oysters, Crassostrea gigas, started at the end of the 1980s. Triploid oysters were first obtained artificially, mainly by chemical processes that inhibited the expulsion of a polar body of eggs following their fertilization to obtain an additional set of chromosomes (Stanley et al., 1981; Allen and Downing, 1986; see Beaumont and Fairbrother, 1991).

However, chemical methods are imperfect and cannot guarantee the production 、 \& 100\% triploid animals (Gérard et al., 1999). Moreover diploids refractory to chemical methods we iound to be more sensitive to environmental conditions than controls, demonstrating a negat.ve ...ect of those treatments on oysters (Goulletquer et al., 1996).

To avoid possible chemical toxicity and obtain fully triplnid progeny, tetraploid male oysters are now crossed with female diploid oysters (Guo et al., 1996; Nell, 200.; b._._odelmouna and Ledu, 2015).

A large number of studies have compared the $t$ nlor,cal characteristics of triploid and diploid oysters. Most of the time, the whole weight and flesh growth $\vee f$ triploid oysters has been observed to be more rapid than that of diploid C. gigas oysters (Allen and Down ig . 396; Shpigel et al., 1992; Goulletquer et al., 1996; Nell, 2002; Garnier-Géré et al., 2002; Nell and Pe* ins, 2005; Normand et al., 2009; McCarthy et al., 2016; Payton et al., 2017) but also in that of other oyst. * su - ies like Crassostrea virginica (Dégremont et al., 2012) and Saccostrea glomerata (Hand et al. 2004). This ${ }^{2}$ nomenon can be explained by the partial sterility of triploid oysters which invest less energy in produ 'ng gumetes than in growth of the shell and soma (Allen and Downing, 1986; Hand et Nell, 1999; Nell, 2002; Gaınier-Géré et al., 2002).

The higher heterozygosity in triploid animals could also explain these results due to a greater probability of possessing several alleles per locus (Guo et al., 1996), leading to beneficial effects on feeding and energy accumulation (Hawkins et al., 2000).

The energy costs linked to metabolism are assumed to be low in triploid oysters and suggest greater resistance to stress than diploid oysters (Shpigel et al., 1992; Garnier-Gere et al., 2002).

Nonetheless, the results have led to controversy regarding diploid and triploid oysters during mortality episodes. Thus, according to studies, the rates of survival of triploid oysters have been observed to be lower (Goulletquer et al., 1996) or higher (Allen and Dawning, 1986) than those of diploids, probably in relation to the cause or 
causes of mortality. In addition, a recent study showed that the level of ploidy does not influence the rate of mortality in C.gigas exposed to OsHV-1 and that it was lower only in diploids and triploids whose parents had been selected for their high resistance to OsHV-1 (Dégremont et al. 2016). Moreover; triploid oysters present increased sensitivity to the bacterium Vibrio aestuarianus in relation to their growth potential, given that the sensitivity of $C$. gigas increases with oyster size (Azéma et al., 2016; Azéma et al., 2017).

Today, a large part of French oyster production relies on the supply of triploid animals by hatcheries but the effects of ploidy on the physiological functioning of the oyster remains poorly understood, notably in tetraploid oysters from which triploid oysters are most frequently obtained. Likewise, knowledge is lacking with respect to the physiology of oysters selected for their better resistance to infection by $\iota$ HV-1 and produced by French commercial hatcheries (Dégremont et al., 2019).

The objective of the present study is to investigate the clearance and o yges consumption rates of Pacific cupped oysters at different levels of ploidy $(2 n, 3 n$ and $4 n)$ and res: $: n c$ to infection by OsHV-1 (selected and controls), in a habitat free of known pathogenic organisms. 


\section{Material and methods}

\subsection{Biological material and acclimation procedure}

C. gigas, the oysters studied, were produced in spring 2015 at the Ifremer hatchery of La Tremblade and were bred similarly until the beginning of the experiment at the age of 1 year. During the breeding period, UV treatment (low-pressure UV, $6 \mathrm{~m}^{3} / \mathrm{h}, 33 \mathrm{~mJ} / \mathrm{cm}^{2}$ ) was applied to protect the oysters from pathogenic organisms liable to be present in the Marennes-Oléron basin. They were divided into two groups of animals as a function of their resistance or sensitivity to OsHV-1. Each of the two groups was romposed of diploid, triploid and tetraploid oysters with the same genetic background to minimize the e rect if parental origin. The tetraploid oysters were obtained in 2015 from two stocks of diploid oysters seler ted c · not in relation to OsHV-1 according to the direct induction method described by Benabdelmouna \& I edu ?015). The production of tetraploid stocks was subjected to thorough follow-up throughout their zootechnic. ' ycle. Thus, every step of the production of tetraploid stocks was carried out in secured areas with li ni ec access and whose effluents were systematically treated by filtration and ozonation-chlorination $b \ldots \bullet$ ing discharged. In addition, in view to protecting the tetraploids from external hazards, the different rooı - in which the tetraploid stocks were supplied with filtered, thermo-regulated seawater treated with a donhle $\mathrm{TV}$ barrier (low-pressure $\mathrm{UV}, 6 \mathrm{~m}^{3} / \mathrm{h}, 33 \mathrm{~mJ} / \mathrm{cm}^{2}$ ). In order to produce the different batches used in this dy for each genetic background, the tetraploid oysters were reproduced by fertilization between etraץ ${ }^{1}$ oid males and females to produce batches of tetraploid spats. The same procedure was followed b: proc cing diploid genitors to produce the batches of diploid spats. Lastly, in view to producing the triploic batc es, the sperm from the male tetraploids was used to fertilize the oocytes from corresponding female diploids in order to produce a $100 \%$ triploid progeny. For each reproduction, at least ten males and females were used to avoid consanguinity. The ploidy of each group was verified at every stage of their production cycle (larvae, micro-spats and juveniles) by flow cytometry as per the method described by Benabdelmouna \& Ledu (2015). In total, six groups of 18 oysters were studied after each of them was analyzed by flow cytometry and weighed individually (table 1).

The oysters were sampled in their breeding tank one week before the acquisition of physiological measures (nutrition and respiration) to be progressively acclimated to the experimental conditions corresponding to filtered $(1 \mu \mathrm{m})$ and thermoregulated $\left(21^{\circ} \mathrm{C}\right)$ seawater enriched with the cells of the microalgae Isochrysis affinis galbana (clone T-Iso) (30-40 cells/ $\mu \mathrm{l})$. 


\subsection{Physiological measurements and daily growth rate}

The physiological measures were performed in the Ifremer laboratory at La Tremblade which is equipped with apparatus allowing the individual and simultaneous acquisition of clearance rate $\left(\mathrm{CR}, 1 \mathrm{~h}^{-1}\right)$ and oxygen consumption (OCR, $\mathrm{mg} \mathrm{h}^{-1}$ ) of marine bivalves (Haure et al., 2003). The set-up consists of sixteen chambers each having a volume of 2 liters and supplied continuously (Figure 1) (François et al., 2020). The treated seawater (filtration at $1 \mu \mathrm{m}$ and sterilization by UV) and the phytoplankton Isochrysis affinis galbana (clone TIso) were mixed in a tank (1), then distributed by pump (2) to fifteen chambers (3), each containing a single oyster, plus a control chamber without oysters (4). The phytoplankton Isochrysis affinis galbana (clone T-Iso) was supplied continuously to maintain the concentration of nutrients between `ר and 40 cells / $\mu$ l. The flowrate of each chamber was set at $131 \mathrm{~h}^{-1}$ so that the oysters used no more than $3 \mathrm{~m}$, f phytoplankton resources (Smaal and Widdows, 1994). An air diffuser was placed in the tank (1) to .... intain 80\% oxygen availability. Each measurement chamber (volume 2 1) was equipped with an electı oma a computer (6). When the electromagnetic valve in a measl. emen analyzed every second for 1 minute with an oximeter (Has ${ }^{h}$ __ange Orbisphere 410 with a M1100 LDO probe) (7) to determine the oxygen consumption, then flu rometer (Seapoint Chlorophyll-a Fluorometer SCF) (8) to estimate the clearance rate. The fluorometer. nd oximeter were checked before each test. During this period, the water of the other chambers was removed va avacuation circuit (9). After one minute, the cycle ended for the analysis of the next chamber. The dat? wer averaged for the acquisition of the last 5 seconds of the chamber being measured while the first $55 \mathrm{se}$ nds corresponded to rinsing the residual seawater from the previous chamber in the conduit. Thus. the a vity of an oyster was measured every 16 minutes for a total time of 129 minutes (8 acquisitions of, rec..... in 129 minutes).

At the end of each test, the 1 lesh of the oyster was separated from the shell and frozen at $-20{ }^{\circ} \mathrm{C}$ before being lyophilized for 48 hours and weighed to within $0.01 \mathrm{~g}$.

The clearance rate was calculated as follows:

Clearance rate $(\mathrm{CR})\left(1 \mathrm{~h}^{-1}\right)=\mathrm{F} \times[(\mathrm{I}-\mathrm{O}) / \mathrm{I}]$

where $\mathrm{F}$ is the flow rate $\left(\mathrm{h} \mathrm{h}^{-1}\right)$ of each measurement chamber; $\mathrm{I}=$ fluorescence measured at the outlet of the control chamber; O the fluorescence measured at the outlet of the experimental chamber (Haure et al., 2003).

The oxygen consumption was calculated as follows:

Oxygen consumption rate $(\mathrm{OCR})\left(\mathrm{mg} \mathrm{h}^{-1}\right)=\mathrm{F} x(\mathrm{I}-\mathrm{O})$ 
where $\mathrm{F}$ is the flowrate $\left(\mathrm{h}^{-1}\right)$ of each measurement chamber; $\mathrm{I}=$ oxygen $\left(\mathrm{mg}^{-1}\right)$ measured at the outlet of the control chamber; $\mathrm{O}=$ oxygen measured at the outlet of the experimental chamber (Haure et al., 2003).

The CR and OCR values have been standardized to the physiological activity of an oyster of $1 \mathrm{~g}$ (Bayne and Newell, 1983) using the following formula:

$$
\mathrm{Ys}=(\mathrm{Ws} / \mathrm{We})^{\mathrm{b}} \mathrm{x} \mathrm{Ye}
$$

where Ys is the physiological activity of a standard oyster; Ws, the dry weight of a standard oyster $(1 \mathrm{~g})$; We the dry weight of the animal studied, and $\mathrm{b}$ the allometric coefficient corresponding to the physiological parameter.

The allometry coefficients are specific to each physiological activity and to each species.

These different physiological parameters were calculated during periods $\checkmark$ ien the oyster was active, that is to say that the null filtration values and the oxygen consumption rate were $\mathrm{n} \mathrm{t}$ bee $\mathrm{l}$ taken into account.

Parameters have been developed to estimate the duration of activitic $\leqslant$ of ( ysters in relation to the total duration of the experiment (2 h). Bougrier et al. (1998) and Haure et $\div$ ' 2 c $^{7} 3$ ) calculated respiration activity (RTA) expressed as a percentage of the total duration of an experiment . ' $\mathrm{d}$ used the same approach to determine the active feeding time (FTA) of the animal. Previous stu if, 1 ave shown that FTA and RTA are not always identical and may explain differences in growth $\mathrm{r}-\mathrm{ch}$ en - dividuals of the same species (Haure et al., 2003). In the present study, the RTA and the FTA have there re been defined as the time during which the animal was active, divided by the total time of the experi en ? $\mathrm{h}$ ).

To estimate their daily weight ga $\cdot$, the oysters studied were weighed the day the physiological parameters were acquired. Their mass was c. videc by the number of days breeding calculated from the date of fertilization. Daily growth was therefo-e re ative data calculated as follows:

Daily weight growth (DWG) $\left(\mathrm{r} \mathrm{g} \mathrm{d}^{-1}\right)=1000 \mathrm{x}$ Total weight $(\mathrm{g}) /$ Number of days breeding.

\subsection{Statistical analyses}

All the statistical analyses were performed by ANOVA using the Kruskal-Wallis test with the software SigmaStat 3.2 (Gendel Scientific). Multiple pairwise comparisons were performed using the SNK test (Student Newman Keuls method). Since the RTA and FTA were both percentages, the values were normalized by angular transformation. 


\section{Results}

\subsection{Physiological comparison of the families studied}

Table 2 presents the ANOVA performed on all the physiological parameters studied to discriminate the 6 families of 18 individuals each. This analysis revealed that in a habitat not infected with OsHV-1: i) there was no interaction between the levels of ploidy and the selection, ii) the families did not present a significant difference as a function of the level of selection to tolerance to OsHV-1, and iii) there were significant differences in clearance rate and daily weight growth according to the level of ploidy of the iysters.

This is why the data were grouped by level of ploidy only, without taki $\mathrm{g}$ in ) account tolerance to OsHV-1 to form groups of 36 animals.

The results that follow were obtained according to this new gre ing

\subsection{Physiological parameters and dai'y,$e^{i}$ jht growth between ploidy levels}

The average FTA and RTA values were betw en, 6.0 and $89.7 \%$ and 73.2 and $86.8 \%$, respectively, without showing significant differences between ploiu, levels (Fig. 2 and Table 3).

Oxygen consumptions (OCR) did not pe1 ni a _criminating between the families either. They were on average $1.39 \mathrm{mg} \mathrm{l}^{-1} \mathrm{~h}^{-1}$ for the triploid and tetraf' vid oy sters and $1.60 \mathrm{mg} \mathrm{l}^{-1} \mathrm{~h}^{-1}$ for the diploids (Fig. 3 and Table 3).

On the contrary, significant diff, «enc's were observed $(\mathrm{p}<0.001)$ between families with regard to filtration

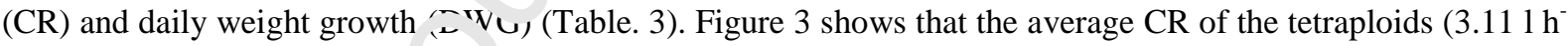
${ }^{1} \mathrm{~g}^{-1}$ ) was significantly lowe han that of the diploids and triploids (5.18 and $4.37 \mathrm{l} \mathrm{h}^{-1} \mathrm{~g}^{-1}$ respectively). The daily weight gains were far higher tor the triploids and tetraploids (58 and $53.7 \mathrm{mg} \mathrm{d}^{-1}$ respectively) with respect to the diploid oysters (28.2 $\left.\mathrm{mg} \mathrm{d}^{-1}\right)$ (Fig. 4).

\section{Discussion}

\subsection{Importance of the origin of biological material}

In order not to confound the potential crossed effects of genetic background, at the level of ploidy and zootechnical history, we used batches of oysters whose age and filiation and breeding history were as close as 
possible. This permitted eliminating experimental biases so that the differences observed between each population of oysters could be attributed only to their different ploidies and to their level of tolerance to OsHV-1. It was essential to have this level of quality available for the biological material to avoid hazardous conclusions. Thus, among the many works performed to measure the resistance to stress of oysters as a function of their ploidy, certain of them concluded that triploids survived better (Gagnaire et al., 2006) whereas others found no significant differences between diploids and triploids (Duchemin et al., 2007) originating from different French regions. As indicated by Piferrer et al. (2009), the possibility that these contradictory results are related to genetic contexts (hatchery $v s$ wild) or to different breeding histories and geographic sources of the animals used should not be ignored.

A study using diploid and triploid oyster families with the same genetic bası and breeding history was finally able to show that the level of ploidy did not influence the mortality $r$, te of C.gigas in relation to OsHV-1. Only the genetic basis of the genitors used had an influence on the rrvival performances of batches $2 \mathrm{n}$ and $3 \mathrm{n}$, notably increased survival for the two levels of ploidy when th? $\mu$. rents had been selected for higher resistance to OsHV-1 (Dégremont et al. 2016).

\subsection{Physiological comparisons}

To our knowledge, although few work: $\mathrm{h}{ }_{\curlywedge} \mathrm{V}_{\mathrm{l}}$ been conducted on the physiological comparison of triploid oysters, none at all have included tetra ${ }_{1}{ }^{1}$ oid uysters up to now. This can certainly be explained by the fact that tetraploid Pacific oysters are not $\omega$ dic ted to human consumption but to reproduction for the production of triploid oysters after crossing $\cdots$ tenale diploids. Furthermore, the tetraploid oysters were strictly isolated from the natural environment in structures at Ifremer equipped with water treatment processes to prevent the dissemination of gametes and larvae (Piferrer et al., 2009) and few research organizations and hatcheries are equipped with such systems.

The physiological results of our study were compared to those found in the literature (Table 4). These works were chosen because their experimental approaches, the measures performed and the ploidy level of the oysters studied were similar to ours (except for the $4 \mathrm{n}$ ). Thus, they were carried out in the laboratory at constant temperatures, with filtered seawater and the controlled addition of phytoplankton to ensure the repeatability of the experimental conditions. The activity times linked to CR and OCR (FTA and RTA) measured in our study did not permit discriminating the oysters as a function of their ploidy level or tolerance to OsHV-1 and 
conformed to previous studies performed on diploid (Bougrier et al., 1995; Haure et al., 2003a; Haure et al. 2003b) and triploid (Haure et al., 2003b) C. gigas oysters and diploid Crassostrea angulata (Haure et al. 2003b).

In addition, table 4 shows that the OCR and CR values differ between diploid and triploid animals in C. gigas. Our observations are close to those found in C. gigas and C. angulata (Bougrier et al., 1995; Akashige et al., 2005; Haure et al., 2003a) but higher than the values obtained with Saccostrea commercialis (Kesarcodi-Watson et al., 200a; Kesarcodi-Watson et al., 2001b). The comparison of our observations with those of previous studies is not easy and comes up against the considerable variability of the results, probably due to the different procedural modes implemented. A recent study performed on the determination of reference CR and OCR values for $C$. gigas pointed to the difficulty of comparing different studies with ach other when the experimental conditions are not standardized (François et al., 2020). The authors reco. mme ded that researchers should work with a homogenous population of oysters, provide a supply of micro lgae of constant quality and quantity, and have good control over experimental conditions (especially temp ... ${ }^{+} \mathrm{uI}_{\mathrm{N}}$, salinity and flowrate).

In our study, the DWG results showed that the $3 \mathrm{n}$ and $4 \mathrm{n}$ oysters ad better growth rates than the $2 \mathrm{n}$. Although no comparison was possible with the tetraploid oysters, $\mathrm{t}^{\mathrm{t}} \mathrm{e}$ iterature abounds with studies in which triploid oysters presented higher weight growths than 11 pias (Allen and Downing, 1986; Shpigel et al., 1992; Goulletquer et al., 1996; Nell, 2002; Garnier-Géré ` al., 2002; Nell and Perkins, 2005; Normand et al., 2009; McCarthy et al., 2016; Payton et al., 2017).

Furthermore, it was not possible to usf $2 \mathrm{Ch} . \mathrm{v}$ discriminate populations as a function of their ploidy, although the statistical analysis of the CR res "ts aı Jwed defining two statistically homogenous groups, one comprising diploids and triploids of the samc affic sncy, and the other with tetraploids with a lower average CR.

Similar studies were nert rme $/$ by Kesarcodi-Watson et al. (2001a and 2001b) on the physiological comparison of diploid and tr ploid oysters of the genus Saccostrea commercialis. They observed a lower metabolic cost in triploids, linked to OCR and lower ammonia excretion, leading to a higher Scope for growth (SFG) than in the diploids. However, and according to the authors, this significant difference in SFG cannot explain, alone, the better growths of the triploid oysters. They hypothesized that the diploid and triploid oysters could distribute energy differently for shell, soma and gonad growth. In triploid animals, the little energy intended for reproduction leaves a large share of SFG for tissue and shell growth (Kesarcodi-Watson et al., 2001b). Hawkins et al. (2000) also showed better growth, feeding rate, absorption efficiency and SFG performances in triploid Pacific oysters in comparison to diploid oysters. Like Kesarcodi-Watson et al. (2001a ; 2001b), they attributed these results to the partial or total sterility of triploid oysters versus their diploid 
counterparts, but they highlighted that the physiological performances increased when triploid animals were obtained by inhibiting the expulsion of polar globule 1 (GP1) in comparison to those produced through the inhibition of the expulsion of polar globule 2 (GP2). They therefore formulated the hypothesis that the heterozygosity of triploid oysters, notably those obtained with meiosis I, could explain their better physiological performances versus diploid oysters.

The heterozygotic richness of polyploids and in particular tetraploids could also explain the better growths of tetraploid oysters despite the contribution of energy linked to reproduction. Regarding this, it might be assumed that tetraploid oysters devote less energy to reproduction than diploid oysters. Our study cannot answer this hypothesis because it was performed outside the reproduction period and th o oametogenesis of the oysters could not be estimated. However, this hypothesis should be taken into account : nce has been observed in mud loach (Misgurnus mizolepis) populations, in which 25\% of the tetraploid an nals lid not develop gonads or these were significantly reduced (Nam and Kim, 2004).

The CR of the tetraploids were significantly lower than those of the diploids and triploids, revealing less efficiency in retaining nutrient particles in the gills. $\mathrm{Tl}$ is su sgests that to justify their growth performance, tetraploids may have more efficient absorption ar $\_$a sim. ' by Hawkins et al. (2000) in triploid oysters. Further.. rre, the comparative examination of polyploid and diploid gills could provide information on the low $C^{n}$ ot . traploids. A study has shown that the gill surface to dry flesh weight ratio of oysters was significant', hig...r in triploid Pacific oysters than in their diploid counterparts (Haure et al., 2003b).

Our study did not allov $d$. scrin inating families according to their level of OsHV-1 resistance selection. It should be recalled that these es periments were performed in a clean environment and that the factor of OsHV-1 selection level was not tested in an infected environment. These results are nonetheless interesting since they suggest that the physiological functions studied were apparently not influenced during selection to OsHV-1 or by a clean environment. These points to the interest of performing a systematic physiological characterization of any species subject to selection in order to improve its human exploitation and thus its domestication. This characterization should take into account three precautions before any introduction into the natural environment: i) verification of the existence and persistence of the characteristic(s) selected, ii) control of continued physiological performance following selection, and iii) the sterilization of the populations selected, notably by triploidization, to avoid their propagation in the natural environment. 
Lastly, this study raises many questions on the physical functioning of tetraploid Pacific oysters, C. gigas, in particular their higher growth performance than that of diploids. To answer these questions, additional works must be performed to validate these initial results and compare the energy dedicated to reproduction between diploid and tetraploid C. gigas oysters. 


\section{References}

Allen S.K \& Downing S.L., 1986. Performance of triploid Pacific oysters, Crassostrea gigas (Thunberg). I. Survival, growth, glycogen content, and sexual maturation in yearlings. J. Exp. Mar. Biol. Ecol.102, 197-208.

Bayne B.L., Newell R.C., 1983. Physiological energetics of marine molluscs. In: Wilbur KM, Saleuddin AS, eds. The Mollusca. New York, NY: Academic Press, 4: 407-515.

Beaumont A.R \& Fairbrother J.E., 1991. Ploidy manipulation in molluscan allfish: a review. J. Shellfish Res. $10(1), 1-18$.

Benabdelmouna A., Ledu C., 2015. Autotetraploid Pacific oy cen (Lrassostrea gigas) obtained using normal diploid eggs: induction and impact on cytogenetic stability. Ger omc 58(7), 333-348.

Bougrier S, Geairon P, Deslous-Paoli JM, Bache' C, . onquières G., 1995. Allometric relationships and effects of temperature on clearance and oxygen consumption $\mathrm{r}_{\mathrm{a}}$ es of Crassostrea gigas (Thunberg). Aquaculture 134(1), 143-154.

Bougrier S., Collet B., Geairon P., G ffard O., Héral M., Deslous-Paoli J.M., 1998. Respiratory time activity of the Japanese oyster Crassostrea gi ${ }^{\circ}$ as 'Thunberg). J. Exp. Mar. Biol. Ecol. 219, 205-216.

Dégremont L., Ledu C., Mz`r uard E., Nourry M., Benabdelmouna A., 2016. Effect of ploidy on the mortality of Crassostrea gigas spat caused by OsHV-1 resistant oysters. Aquac. Res. 47, 777-786.

Duchemin M., Fournier M., Auffret M., 2007. Seasonal variations of immune parameters in diploid and triploid Pacific oysters, Crassostrea gigas (Thunberg). Aquaculture 264, 73-81.

François C., Haure J., Billy J.C., Renault T., 2020. Toward reference intervals for shellfish: An illustrative case of feeding and respiratory activities in the Pacific cupped oyster, Crassostrea gigas. Vet. Clin. Pathol. 49, 345353. 
Gagnaire B., Soletchnik P., Madec P., Geairon P., Le Moine O., Renault T., 2006. Diploid and triploid Pacific oysters, Crassostrea gigas (Thunberg), reared at two heights above sediment in Marennes-Oleron Basin, France: Difference in mortality, sexual maturation and hemocyte parameters. Aquaculture 254(1-4), 606-616.

Garnier-Géré P.H., Naciri-Graven Y., Bougrier S., Magoulas A., Héral M., Kotoulas G., Hawkins A., Gérard A., 2002. Influences of triploidy, parentage and genetic diversity on growth of the Pacific oyster Crassostrea gigas reared in contrasting natural environments. Mol. Ecol. 11, 1499-1514.

Gérard A., Ledu C., Phélipot P., Naciri-Graven Y., 1999. The induction of $\mathrm{N}_{\text {I }}$ and MII triploids in the Pacific oyster Crassostrea gigas with 6-DMAP or CB. Aquaculture 174, 229- ?.42.

Goulletquer P., Joly J.P., Gérard A., Le Gagneur, E., Moriceru, , Peignon J.M., Heurtebise S., Phelipot P., 1996. Performance of triploid Pacific Oysters Crassostr 'o gl as (Thunberg) reared in high carrying capacity ecosystem : survival, growth and proximate bioch $m_{\iota}$ al c mposition. Haliotis 25, 1-12.

Guo X., DeBrosse G.A., Allen, S.K., 1996. ^1l-ı ’ ploid Pacific oysters (Crassostrea gigas Thunberg) produced by mating tetraploids and diploids. Aqua _ ${ }^{1}+u_{1}-142(3), 149-161$.

Hand R.E. and Nell J.A., 1999. Stud is on triploid oysters in Australia XII. Gonad discolouration and meat condition of diploid and tripl id S dney rock oysters (Saccostrea commercialis) in five estuaries in New South Wales, Australia. Aquaculture 71, 181-194.

Haure J., Huvet A., Palvadeau H., Nourry M., Penisson C., Martin J.L.Y., 2003a. Feeding and respiratory time activities in the cupped oysters Crassostrea gigas, Crassostrea angulata and their hybrids. Aquaculture 218(1), $539-551$

Haure J., Fortin A., Dupuy B., Nourry M., Palvadeau H., Papin M., Penisson C., Martin J.L., 2003b. Etude comparative des caractéristiques écophysiologiques et des performances de croissance de l'huître creuse Crassostrea gigas diploïde et triploïde en milieu contrôlé. https://archimer.ifremer.fr/doc/00000/1509/ 
Hawkins A.J.S., Magoulas A., Héral M., Bougrier S., Naciri-Graven Y., Day A.J., Kotoulas G., 2000. Separate effects of triploidy, parentage and genomic diversity upon feeding behaviour, metabolic efficiency and net energy balance in the Pacific oyster Crassostrea gigas. Genet. Res., Camb. 76, 273-284.

Kesarcodi-Watson A., Lucas J.S., Klumpp D.W., 2001a. Comparative feeding and physiological energetics of diploid and triploid Sydney rock oysters, Saccostrea commercialis. I. Effects of oyster size. Aquaculture 203, 177-193.

Kesarcodi-Watson A., Klumpp D.W., Lucas J.S., 2001b. Comparative f edin ; and physiological energetics of diploid and triploid Sydney rock oysters, (Saccostrea commercialis, II. nfluences of food concentration and tissue energy distribution. Aquaculture 203, 195-216.

McCarthy A., Crawford C., Eriken R., Ross D.J., 2016. D et „ry preferences, growth and condition of triploid and diploid Pacific oysters, Crassostrea gigas (Thunt ary, in 'ittle Swanport Estuary, Tasmania, Australia. Aquac. Res. 47, 3352-3358.

Nam Y.K., Kim D.S., 2004. Ploidy sta' . oi rogeny from the crosses between tetraploid males and diploid females in mud loach (Misgurnus mi- lepı). Aquaculture 236(1-4), 575-582.

Nell J. A., 2002. Farming trip. jid c ysters. Aquaculture 210, 69-88.

Nell J. A., Perkins B., 2005. Studies on triploid oysters in Australia: farming potential of all-triploid Pacific oysters, Crassostrea gigas (Thunberg), in port Stephens, New South Wales, Australia. Aquac. Res. 36, 530-536.

Normand J., Ernande B., Haure J., McCombie H., Boudry P., 2009. Reproductive effort and growth in Crassostrea gigas: comparison of young diploid and triploid oysters issued from natural crosses or chemical induction. Aquat. Biol. 7, 229-241. 
Payton L., Sow M., Massabuau J.C., Ciret P., Tran D., 2017. How annual course of photoperiod shapes seasonal behaviour of diploid and triploid oysters, Crassostrea gigas. PLoS ONE 12(10), 1-21.

Piferrer F., Beaumont A., Falguière J.C., Flajshans M., Haffray P., Colombo L., 2009. Polyploid fish and shellfish: Production, biology and applications to aquaculture for performance improvement and genetic containment. Aquaculture 293(3-4), 125-156.

Shpigel M., Barber B.J., Mann R., 1992. Effects of elevated temperature on growth, gametogenesis, physiology, and biochemical composition in diploid and triploid Pacific oysters, Crass trea gigas Thunberg. J. Exp. Mar. Ecol. 161, 15-25.

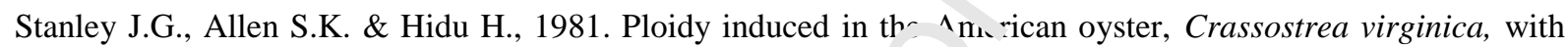
cytochalasin B. Aquaculture 23, 1-10.

Smaal AC, Widdows J., 1994. The scope for src vth of bivalves as an integrated response parameter in biological monitoring. In: Kramer KJM, ed. Biome itoring of coastal waters and estuaries. Boca Raton, FL: CRC Press: 247-267.

Zhou L., Gui J., 2017. Natural and ar` ficiaı polyploids in aquaculture. Aquaculture and fisheries 2, 103-111. 


\section{Acknowledgements}

The authors wish to thank the hatchery team of the Ifremer station at La Tremblade, France. This research was funded in the framework of the EU project VIVALDI (H2020 program no.678589).

Disclosure: The authors indicate that they have no affiliations or financial involvement with any organization or entity with a financial interest in, or in financial competition with, the subject matter or materials discussed in this article.

\section{Figures}

Figure 1. Experimental design for clearance rate and oxygen consu- ‘ntion measurements.

1: intake of treated seawater and phytoplankton; 2: pump fc- inle adjustment; 3: measurement chamber; 4: control unit; 5: outlet valve control; 6: computer; 7: oxyger ${ }^{\circ}{ }^{\circ}$ obe; 8: tluorometer; 9: waste circuit.

Figure 2. Comparison of feeding time activity (FTA, and respiratory time activity (RTA) of oyster populations of different ploidy levels.

Figure 3. Comparison of clearance rat (CR) and oxygen consumption rate (OCR) of oyster populations of different ploidy levels.

Figure 4. Comparison of daily weight growth (DWG) of oyster populations of different ploidy levels. 


\section{Tables}

Table 1. Total average weight of oyster populations as a function of their ploidy and level of resistance to OsHV-1.

\begin{tabular}{ccc}
\hline Ploidy & $\begin{array}{c}\text { Total mean weight }(\mathrm{g}) \\
\text { Unselected family } \\
(\text { OsHV-1) }\end{array}$ & $\begin{array}{c}\text { Total mean weight }(\mathrm{g}) \\
\text { Selected family }(\text { OsHV- } \\
1)\end{array}$ \\
\hline $2 \mathrm{n}$ & $15.4(8.8)$ & $11.2(6.2)$ \\
$3 \mathrm{n}$ & $28.5(5.5)$ & $25.0(8.5)$ \\
$4 \mathrm{n}$ & $27.8(9.7)$ & $24.0(7.8)$ \\
\hline
\end{tabular}

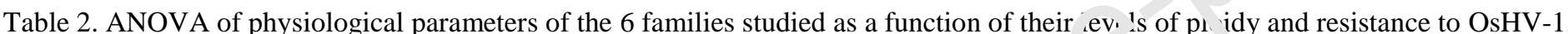

\begin{tabular}{|c|c|c|c|c|c|c|c|c|c|c|c|}
\hline \multirow[b]{2}{*}{ Source of variation } & \multirow[b]{2}{*}{ DF } & \multicolumn{2}{|c|}{$\mathrm{CR}\left(1 \mathrm{~h}^{-1} \mathrm{~g}^{-1}\right)$} & \multicolumn{2}{|c|}{ OCR $\left(\mathrm{mg} \mathrm{h}^{-1} \mathrm{~g}^{-1}\right)$} & \multicolumn{2}{|c|}{$\mathrm{F}^{\mathrm{T}} \mathrm{A}(\%}$, & \multicolumn{2}{|c|}{ RTA $(\%)$} & \multicolumn{2}{|c|}{$\mathrm{DWG}\left(\mathrm{mg} \mathrm{d}^{-1}\right)$} \\
\hline & & $\mathrm{F}$ & p-value & $\mathrm{F}$ & $p$-value & $\underline{F}$ & $p$-value & $\mathrm{F}$ & p-value & $\mathrm{F}$ & $p$-value \\
\hline Selection Level & 1 & 0.46 & 0.499 & 2.794 & 0.097 & ८. 046 & 0.831 & 3.059 & 0.083 & 0.046 & 0.83 \\
\hline Polyploidy & 2 & 9.598 & $<0.001 *$ & 2.016 & ר 13 & 0.375 & 0.688 & 1.612 & 0.204 & 3.913 & $0.023^{*}$ \\
\hline Selection Level x Polyploidy & 2 & 0.429 & 0.652 & 0.857 & 0.427 & 0.024 & 0.976 & 2.278 & 0.107 & 0.717 & 0.49 \\
\hline
\end{tabular}

*Significant $(\mathrm{P}<0.05)$ ANOVA for the model. 


\section{Journal Pre-proof}

Table 3. Statistical comparison of physiological parameters of $C$. gigas oysters studied as a function of their ploidy level.

\begin{tabular}{|c|c|c|c|c|c|c|}
\hline Physiological parameters & Ploidy & $\mathrm{n}$ & Mean (SD) & $F$-test & $p$-value & SNK \\
\hline \multirow[t]{3}{*}{ Clearance rate, $\mathrm{CR}\left(1 \mathrm{~h}^{-1} \mathrm{~g}^{-1}\right)$} & $2 n$ & 36 & $5.18(2.43)$ & & & $\mathrm{A}$ \\
\hline & $3 n$ & 36 & $4.37(2.41)$ & 8.27 & $<0.001 *$ & A \\
\hline & $4 n$ & 36 & $3.11(1.55)$ & & & $\mathrm{B}$ \\
\hline \multirow[t]{3}{*}{ Oxygen consumption rate, OCR $\left(\mathrm{mg} \mathrm{h}^{-1} \mathrm{~g}^{-1}\right)$} & $2 n$ & 36 & $1.60(0.53)$ & & & \\
\hline & $3 n$ & 36 & $1.39(0.67)$ & 1.7 & 0.187 & N.S. \\
\hline & $4 n$ & 36 & $1.39(0.45)$ & & & \\
\hline \multirow[t]{3}{*}{ Feeding time activity, FTA $(\%)$} & $2 n$ & 36 & $89.7(16.4)$ & & & \\
\hline & $3 n$ & 36 & $86.0(23.9)$ & 0.305 & $0.7 ?$ & AS. \\
\hline & $4 n$ & 36 & $86.8(22.3)$ & & & \\
\hline \multirow[t]{3}{*}{ Respiration time activity, RTA (\%) } & $2 n$ & 36 & $73.2(25.5)$ & & & \\
\hline & $3 n$ & 36 & $81.0(25 . \cdot)$ & 1.14 & 0.356 & N.S. \\
\hline & $4 n$ & 36 & $80 . \AA(24.5)$ & & & \\
\hline \multirow[t]{3}{*}{ Daily weight growth, DWG (mg d $\left.{ }^{-1}\right)$} & $2 n$ & 36 & ง.. $\left(1^{3} .6\right)$ & & & B \\
\hline & $3 n$ & $3 f$ & $5.0, \triangle 8.6)$ & 13.78 & $<0.001 *$ & A \\
\hline & $4 n$ & $3 i$ & ${ }_{4} 9.8(29.5)$ & & & A \\
\hline
\end{tabular}

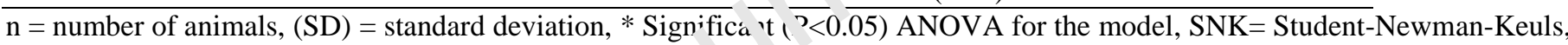

$F$-test $=$ test de Fisher. 
Journal Pre-proof

Table 4: Comparison of physiological averages of oysters observed in the literature with those of this study.

\begin{tabular}{|c|c|c|c|c|c|c|c|c|}
\hline Ploidy & Species & Temperature $\left({ }^{\circ} \mathrm{C}\right)$ & $\mathrm{n}$ & $\mathrm{CR}\left(1 \mathrm{~h}^{-1} \mathrm{~g}^{-1}\right)$ & $\operatorname{OCR}\left(\mathrm{mg} \mathrm{h}^{-1} \mathrm{~g}^{-1}\right)$ & $\begin{array}{l}\text { FTA } \\
(\%)\end{array}$ & RTA $(\%)$ & References \\
\hline $2 \mathrm{n}$ & C. gigas & 20 & 28 & 4.28 & & & & Bougrier et al., 1995 \\
\hline $2 n$ & C. gigas & 20 & 12 & 3.37 & & & & Bougrier et al., 1995 \\
\hline $2 n$ & C. gigas & 20 & 27 & & 0.86 & & & Bougrier et al., 1995 \\
\hline $2 \mathrm{n}$ & C. gigas & 20 & 22 & & 1.08 & & 2 & Bougrier et al., 1995 \\
\hline $2 n$ & C. gigas & 20 & 65 & & & & & Bougrier et al., 1998 \\
\hline $2 \mathrm{n}$ & S. commercialis & 23 & 53 & 1.87 & & & & Kesarcodi-Watson et al., 2001a \\
\hline $3 n$ & S. commercialis & 23 & 57 & 1,92 & & & & Kesarcodi-Watson et al., 2001a \\
\hline $2 n$ & S. commercialis & 23 & 80 & & 0.68 & & & Kesarcodi-Watson et al., 2001a \\
\hline $3 n$ & S. commercialis & 23 & 77 & & 062 & & & Kesarcodi-Watson et al., 2001a \\
\hline $2 n$ & S. commercialis & 23 & 22 & 1.31 & & & & Kesarcodi-Watson et al., 2001b \\
\hline $3 n$ & S. commercialis & 23 & 46 & 1.78 & & & & Kesarcodi-Watson et al., 2001b \\
\hline $2 n$ & S. commercialis & 23 & 60 & & 0.59 & & & Kesarcodi-Watson et al., 2001b \\
\hline $3 n$ & S. commercialis & 23 & 29 & & 0.66 & & & Kesarcodi-Watson et al., 2001b \\
\hline $2 n$ & C. gigas & 20 & 35 & $\therefore 3$ & 1.33 & 89 & 97 & Haure et al., 2003a \\
\hline $2 n$ & C. angulata & 20 & 3, & 3.41 & 1.26 & 73 & 98 & Haure et al., 2003a \\
\hline $2 n$ & C. gigas & 15 & 36 & 1.88 & 0.61 & 89 & 89 & Haure et al., 2003b \\
\hline $3 n$ & C. gigas & 15 & 30 & 1.83 & 0.63 & 79 & 89 & Haure et al., 2003b \\
\hline $2 n$ & C. gigas & 21.5 & 16 & 5.10 & & & & Akashige et al., 2005 \\
\hline $2 n$ & C. gigas & 21.5 & 27 & & 0.89 & & & Akashige et al., 2005 \\
\hline $2 n$ & C. gigas & 22 & 214 & 2.08 & 0.86 & & & François et al., 2020 \\
\hline $2 n$ & C. gigas & 21 & 36 & 5.18 & 1.60 & 89.7 & 73.2 & This study \\
\hline $3 n$ & C. gigas & 21 & 36 & 4.37 & 1.39 & 86.0 & 81.0 & This study \\
\hline $4 n$ & C. gigas & 21 & 36 & 3.11 & 1.39 & 86.8 & 80.1 & This study \\
\hline
\end{tabular}

$\mathrm{n}=$ number of animals. 


\section{$\underline{\text { Author Statement }}$}

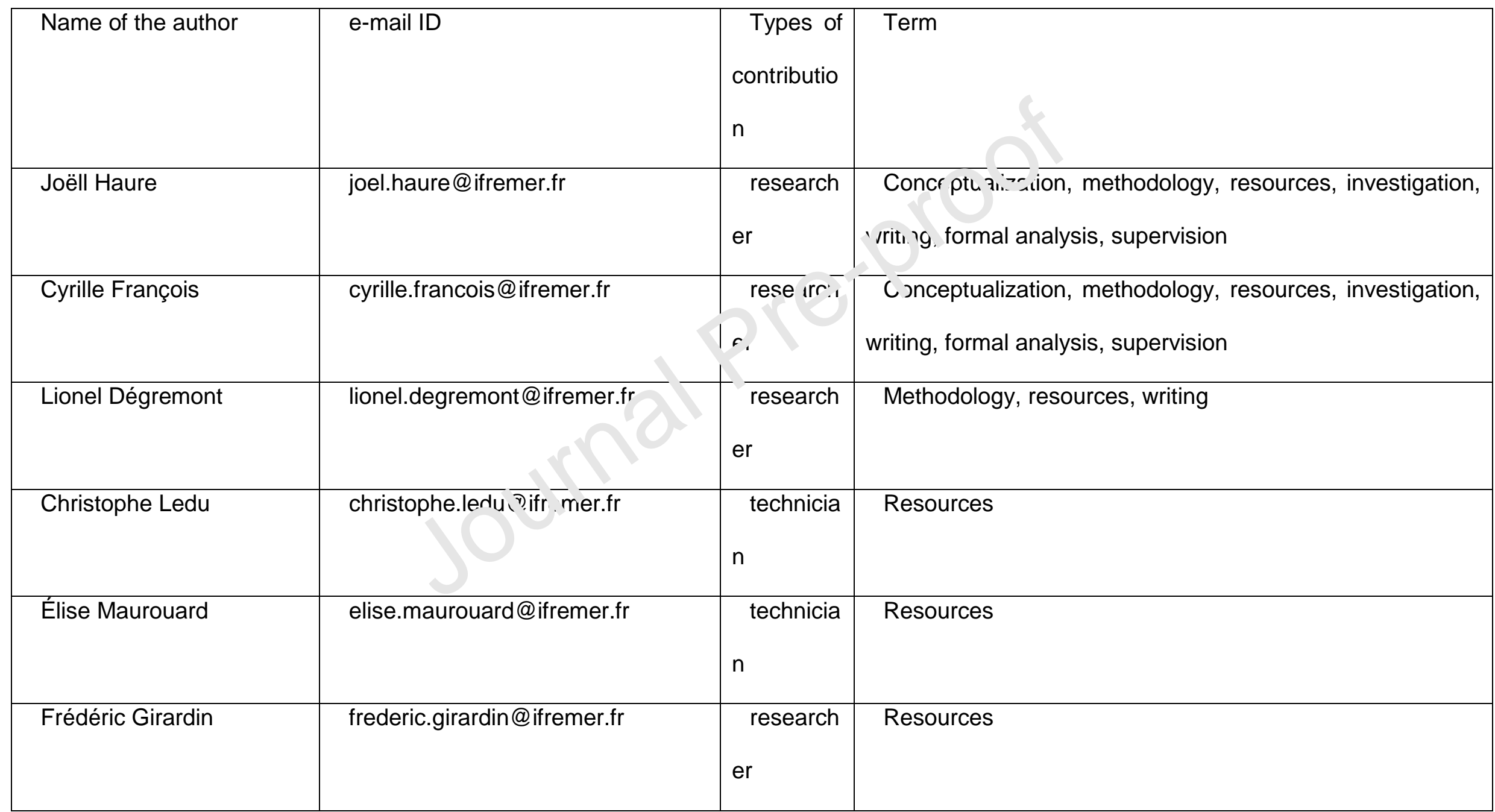




\section{Journal Pre-proof}

\begin{tabular}{|l|l|l|l|}
\hline Abdellah Benabdelmouna & \begin{tabular}{|l|l|} 
abdellah.benabdelmouna@ifremer. \\
$\mathrm{fr}$
\end{tabular} & $\begin{array}{l}\text { research } \\
\text { er }\end{array}$ & Methodology, resources, writing \\
\hline
\end{tabular}




\section{Declaration of interests}

$\bigotimes$ The authors declare that they have no known competing financial interests or personal relationships that could have appeared to influence the work reported in this paper.

$\square$ The authors declare the following financial interests/personal relationships which may be concic erec as potential competing interests:

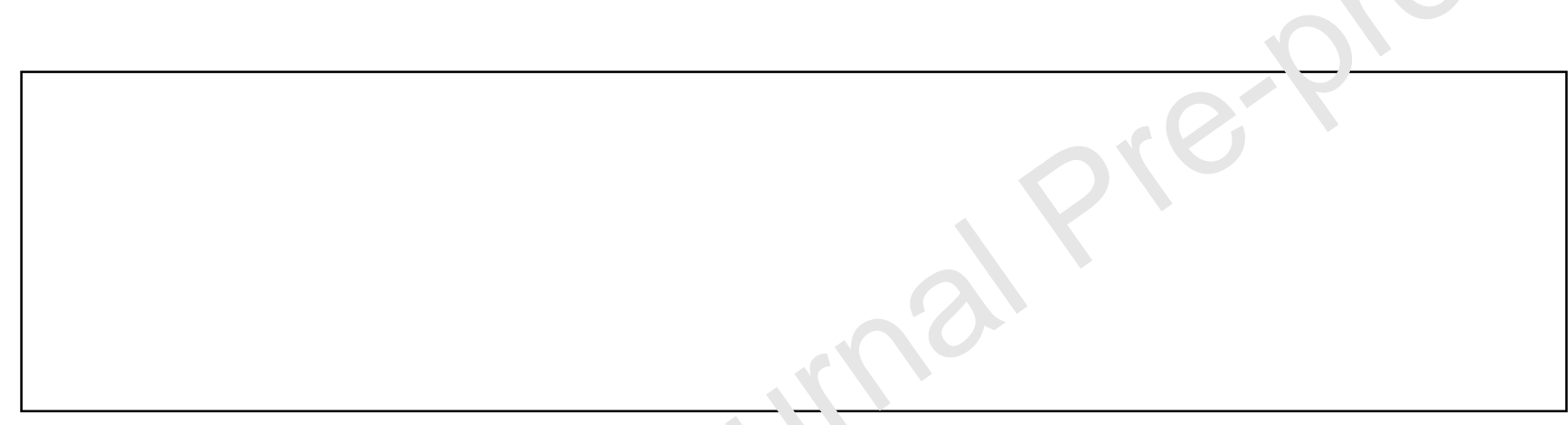


The production and supply of triploid oysters Crassostrea gigas has become an increasingly frequent activity in aquaculture companies to satisfy the growing demand of breeders.

The effects of ploidy and selection for better resistance to pathogens, on the physiological functioning of the Pacific cupped oyster are still relatively unknown, especially in tetraploid oysters.

The interest of this study is to verify the effects of selection and ploidy on the physiological performances of cultivat d oysters. 


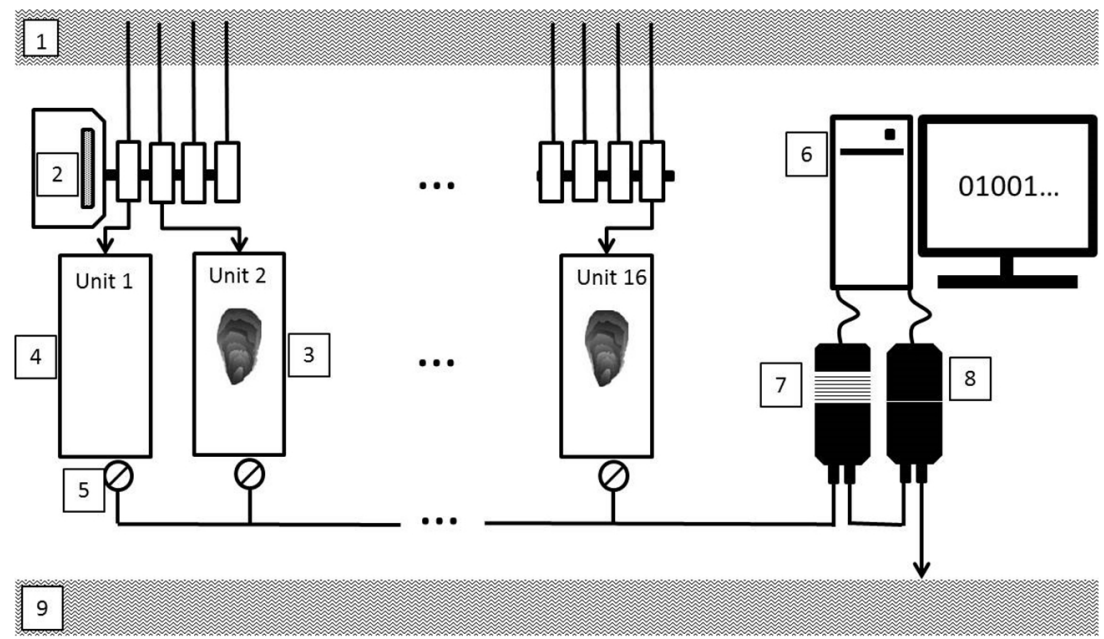

Figure 1 


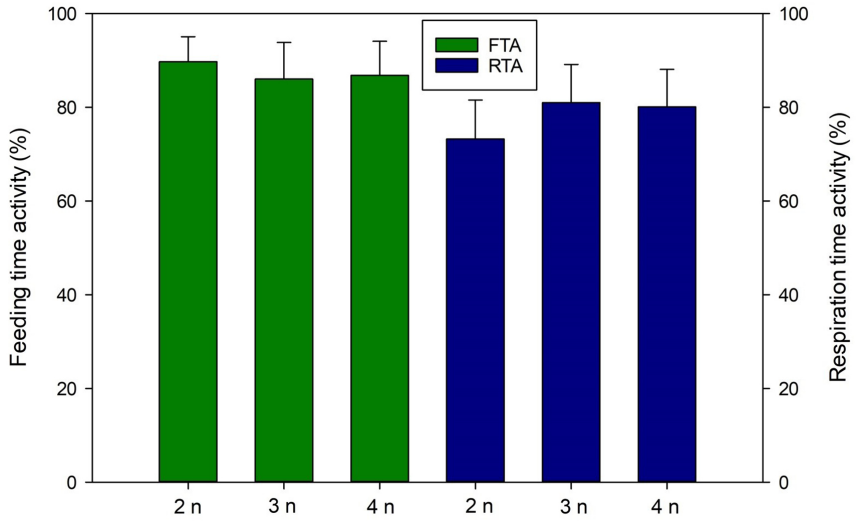

Figure 2 


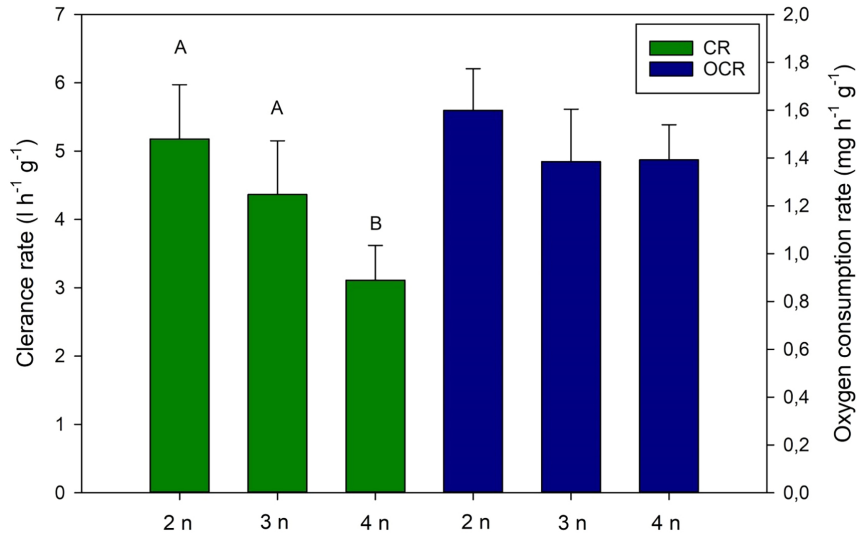

Figure 3 


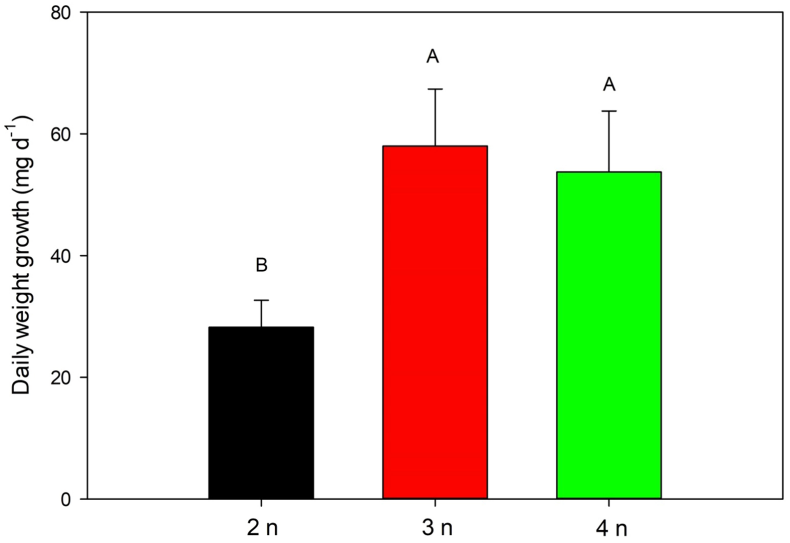

Figure 4 